\title{
A Preliminary Evaluation of Locally Used Plant Coagulants for Household Water Treatment
}

\author{
Moa Megersa $^{1}$ - Abebe Beyene ${ }^{1}$ Argaw Ambelu ${ }^{1} \cdot$ Deres Asnake $^{1} \cdot$ Tesfaye Bekele $^{1} \cdot$ \\ Benti Firdissa $^{1} \cdot$ Zeleke Alebachew $^{2} \cdot$ Ludwig Triest $^{3}$
}

Received: 28 January 2016 /Revised: 31 May 2016/Accepted: 1 June 2016 / Published online: 17 June 2016

(C) Springer Science+Business Media Singapore 2016

\begin{abstract}
Conventional chemical water treatment systems which involve a series of steps are not feasible in rural areas, where a dispersed population is found. Moreover, it is extremely costly for investment in developing countries. Hence, improving drinking water quality at a household level is believed to be effective in fighting waterborne diseases. For this purpose, we investigated the performance of indigenous plant species locally used for turbid water treatment in Ethiopia. Batch
\end{abstract}

Moa Megersa

moamegersa78@gmail.com

Abebe Beyene

abebebh2003@yahoo.com

Argaw Ambelu

aambelu@yahoo.com

Deres Asnake

deresasnake@gmail.com

Tesfaye Bekele

boon.megersa@gmail.com

Benti Firdissa

firdissabenti@yahoo.ca

Zeleke Alebachew

zalebachew@gmail.com

Ludwig Triest

ltriest@vub.ac.be

1 Department of Environmental Health Science and Technology, Jimma University, Jimma, Ethiopia

2 Ethiopian Health and Nutrition Research Institute (EHNRI), Gulele Sub City, Addis Ababa, Ethiopia

3 Plant Science and Nature Management (APNA), Vrije Universiteit Brussel, Pleinlaan 2, 1050 Brussels, Belgium coagulation and microbial reduction experiments were carried out on surface river waters found in Ethiopia having initial turbidities of 20,45, 46, 80, and 195 nephelometric turbidity unit (NTU) with the flocculent dosages of 10, 20, 30, 40, 50, 60, 70, 80, 90, and $100 \mathrm{mg} / \mathrm{l}$. Tubers of Maerua subcordata (Gilg.) DeWolf and seeds of Moringa stenopetala (Baker f.) Cufod. were used for this study, and they were able to achieve appreciable removal efficiency (up to $98 \%$ ) of turbidity at an optimum dose range of 20 to $80 \mathrm{mg} / \mathrm{l}$ in $6 \mathrm{~h}$ of settling time. About $99.9 \%$ of microbial load removal were observed for both $M$. subcordata and M. stenopetala, which is comparable with chlorine disinfection. The experimental result revealed that these plant coagulants were able to meet World Health Organization (WHO) standards of drinking water quality $(<5 \mathrm{NTU})$. This implies that with further optimization, M. subcordata and M. stenopetala can be used as an alternative to household-level water treatment in low-income countries.

Keywords Indigenous plants $\cdot$ Coagulation $\cdot$ Household water treatment $\cdot$ Microbial load $\cdot$ Turbidity

\section{Introduction}

The human right to water entitles everyone to sufficient, safe, acceptable, physically accessible, and affordable water for personal and domestic uses [1]. Nevertheless, unsafe drinking water is a great concern mainly in rural parts of developing countries due to the fact that $75 \%$ of all diseases arise from consumption of untreated water. In Africa, one third of the population has no access to safe water, and almost two thirds have no access to sanitation, causing widespread suffering from waterborne diseases that cause loss of productivity [2]. Water quality is a major problem, as evidenced by frequent outbreaks of waterborne diseases in both rural and urban 
areas. It is also reported that millions of people are at risk of cholera in Ethiopia, where acute watery diarrhea has broken out in crowded and unsanitary conditions of urban and rural areas in 2009 [3].

Although piped water is an important long-term solution in providing safe water, it is very expensive and challenging to implement in rural areas of developing countries. Hence, improving quality of drinking water at a household level is believed to be effective in fighting infectious diarrhea $[4,5]$. It is also reported that household-level water treatment can reduce diarrhea by $71 \%[6]$.

Filtration (ceramic and biosand), chemical disinfection, and solar water disinfection (SODIS) appeared to be frequently used household water treatment techniques in developing countries including Ethiopia [7]. Chlorination appeared among the most promising in terms of effectiveness, affordability, and potential sustainability $[8,9]$ for microbial water treatment. There is no international standard for chlorine dosage in household water treatment, but 1.875 to $3.75 \mathrm{mg} / \mathrm{l} \mathrm{has}$ been recommended for treatment of low- to high-turbidity water [10]. Until recently, the use of chlorine was believed to be safe and concerns about drinking water only focused on eliminating pathogens. However, the chlorine used to reduce the risk of infectious disease may account for a substantial portion of the cancer risk associated with drinking water by forming disinfection by-products (DBPs). More than 250 different types of DBPs have been identified [11]. Aluminum sulfate (Alum), a widely used chemical for coagulation and flocculation, is also reported to affect the nervous system and skeletal problems, with possible connections to several diseases, such as Parkinson's, Alzheimer's [12], and Lou Gehrig's $[13,14]$. Alum also produces large sludge volume [15] and affects the natural alkalinity of water [16]. It is therefore advantageous to look for alternatives to this chemical coagulant with cost-effective, safe, efficient, sustainable, and environmental friendly natural coagulants to offset the aforementioned side effects.

Seed of Moringa oleifera Lam. is one of a widely studied natural coagulant and reported to be the most effective water treatment agent in treating low- to high-turbidity levels of surface water and groundwater [15-20]. Studies also indicated that $M$. oleifera can remove bacterial load in the range of 80$99 \%[19,21]$. Apart from the extensively studied M. oleifera, various other plant materials were reported to have the capability of coagulation and disinfection [22-25]. For instance, [19] tested the coagulation and disinfection ability of Jatropha curcas and Guar gum on well water. The plants showed turbidity removal efficiency up to $71 \%$ on different turbidity levels of well waters found in Malawi. There was also a remarkable reduction in the number of fecal coliforms treated by both plant species. [26] conducted a similar study on J. curcas but on surface water, and the plant coagulated about $60-90 \%$ of suspended matters in the samples. In addition to the abovementioned plant-based coagulants, recent studies indicated coagulation potential of Brassica napus [27], Cocos nucifera [28], Oryza sativa [29], Plantago ovata [30], and Vicia faba [31].

The availability of those plant species may differ from country to country, and it is advantageous to search for new candidate of biocoagulants which are abundantly available in a specified country [32]. This will have enormous advantages in reducing costs that need to be allocated for transportation of plant-based coagulants if the plant is only found in a particular region [20]. Indigenous people in various parts of the world use plant-based coagulants to treat turbid water at household level. For instance, seeds of Vigna unguiculata and Parkinsonia aculeata are used by local people of Tanzania [33], whereas indigenous people of Venezuela use seeds of Cactus latifaria and Prosopis juliflora for turbid water treatment [34].

Similar to other countries, local communities in Ethiopia use natural coagulants to treat turbid water at a household level for their drinking and domestic purposes. Maerua subcordata, Moringa stenopetala, Sansevieria ehrenbergii, and Sansevieria forskaoliana were the four plant species used by local people in Ethiopia; out of which, tubers of M. subcordata (Gilg.) DeWolf and seeds of M. stenopetala (Baker f.) Cufod. appeared to be effective and efficient for purification of low- to high-turbidity surface water [35]. However, the determination of optimum doses for different turbidity levels was the main drawback of using these natural coagulants at household level. Therefore, the main objective of this research was to investigate the coagulation and disinfection potential of locally used indigenous plants (M. subcordata and M. stenopetala) on surface water as to determine optimum doses that help to develop affordable and potent water clarifier with minimal or no human health risks for people in need.

\section{Materials and Methods}

\section{Collection and Preparation of Coagulants}

All the experiments were carried out from February to June 2014 in the laboratory of Environmental Health Science and Technology Department, Jimma University, Ethiopia. The plants used locally for water purification (tuber of M. subcordata and seed of M. stenopetala) were collected from Konso, Jinka, Arbaminch, and Yaballo districts of southern Ethiopia. The plant materials were cleaned by soaking and washing with deionized water (DW) and dried in an oven at $105{ }^{\circ} \mathrm{C}$ for $1 \mathrm{~h}$. The oven-dried plant materials were powdered using a mortar and pestle and homogenized by plant grinder with pore size of $212 \mu \mathrm{m}$. The solution was then prepared by dissolving $5 \mathrm{~g}$ of powder in $100 \mathrm{ml}$ of distilled water. Alum was obtained from Jimma town water treatment plant. About $5 \mathrm{~g}$ of 
Table 1 The physicochemical and biological characteristics of rivers

\begin{tabular}{llllll}
\hline Parameters of natural water & \multicolumn{3}{l}{ Surface water sample site name } & & \\
\cline { 2 - 6 } & Kero & Ofole & Dolollo & Samiche & Gibe \\
\hline Turbidity (NTU) & 20 & 45 & 46 & 80 & 195 \\
Electrical conductivity $(\mu \mathrm{S} / \mathrm{cm})$ & 179 & 121 & 550 & 195 & 657 \\
$\mathrm{pH}$ & 7.29 & 7.36 & 7.81 & 7.86 & 7.95 \\
Temperature $\left({ }^{\circ} \mathrm{C}\right)$ & 24.7 & 26.1 & 29.2 & 29.1 & 27.0 \\
TC $($ colony count per $100 \mathrm{ml})$ & 179 & 167 & 173 & 178 & 189 \\
FC $($ colony count per $100 \mathrm{ml})$ & 152 & 164 & 168 & 159 & 168 \\
E. coli $($ colony count per $100 \mathrm{ml})$ & 166 & 158 & 160 & 153 & 156 \\
HTBC (colony count per $100 \mathrm{ml})$ & 139 & 118 & 129 & 117 & 126 \\
\hline
\end{tabular}

$F C$ fecal coliform, $T C$ total coliform, $H T B C$ heterotrophic bacterial count, $N T U$ nephelometric turbidity unit powder was added to $100 \mathrm{ml}$ of distilled water, and the solution was used for turbidity removal test.

\section{Sampling of Water}

Water samples were collected from Kero, Ofole, Dolollo, Samiche, and Gibe Rivers found in Jimma, Oromia, Ethiopia (Table 1). All samples were collected using clean and sterile polyethylene plastic bottles. The samples were stored in an ice box, transported to the laboratory, and kept in deep freezers until analysis.

\section{Batch Coagulation Experiment}

The batch coagulation experiments were conducted using jar test apparatus that accommodates a series of six beakers (1 1 in size) together with six-spindle steel paddles. We used both positive (turbid water treated with alum) and negative (turbid water without coagulants) controls. The other four samples were treated with different doses of coagulants of M. subcordata and M. stenopetala with a dose range of 10 to $100 \mathrm{mg} / \mathrm{l}$. The coagulants were added before stirring, and the solutions were agitated at a rate of $170 \mathrm{rpm}$ for $3 \mathrm{~min}$ and slowly at $40 \mathrm{rpm}$ for $20 \mathrm{~min}$. After stopping the agitation, the suspensions were allowed to settle for $30 \mathrm{~min}$ and the effective dose with the maximum turbidity removal was recorded. The supernatant of the water samples was taken using a pipette from the middle of the beaker for analysis of physicochemical parameters ( $\mathrm{pH}$, conductivity, temperature, and turbidity) after treatment. The turbidity for each of the water samples was measured after treatment and a 30-min settling period using a turbidity meter consecutively for $6 \mathrm{~h}$. Residual turbidity was measured using a turbidimeter (Oakton T-100), and the $\mathrm{pH}$, conductivity, and temperature were measured using multiparameter probe $(\mathrm{HACH})$. All tests were performed in duplicate at room temperature in the range of 20 to $25^{\circ} \mathrm{C}$.

\section{Microbial Culture Test}

The samples were serially diluted up to $10^{-3} \mathrm{mg} / \mathrm{l}$ for natural surface water. Then, $0.1 \mathrm{ml}$ of each diluent of $10^{-1}$ to $10^{-3} \mathrm{mg} /$ 1 was plated aseptically onto nutrient MacConkey agar for total coliform, M-FC Broth for fecal coliform, and eosin ethylene blue agar for Escherichia coli counts following the standard protocols as described by [36]. Incubation was carried out at $37^{\circ} \mathrm{C}$ for $24 \mathrm{~h}$ for total coliforms and at $44.5^{\circ} \mathrm{C}$ for $24 \mathrm{~h}$ for fecal and E. coli, and the plates were read following standard microbiological procedures [37].

\section{Results and Discussion}

\section{Performance of Plant Coagulants on Turbidity}

The optimum dose found to purify Kero (Fig. 1a) river water by extracts of $M$. subcordata was $70 \mathrm{mg} / \mathrm{l}$ with a turbidity reduction of $75 \%$. Tuber extracts of $M$. subcordata reduced turbidity from 20 to 5 nephelometric turbidity unit (NTU), which was in the range of drinking water guideline set by [38]. However, it was impossible to achieve 5 NTU using seed extracts of M. stenopetala. The extracts of M. stenopetala reduced turbidity of Kero river by $62.5 \%$, at an optimum dosage of $20 \mathrm{mg} / \mathrm{l}$.

Ofole river water (Fig. 1b) had an initial turbidity of $45 \mathrm{NTU}$, and both plant species reduced turbidity to $3 \mathrm{NTU}$ with the optimum dosage of $30 \mathrm{mg} / \mathrm{l}$. The residual turbidity was in the range of drinking water guideline set by [38]. However, dosage above $60 \mathrm{mg} / \mathrm{l}$ reduced turbidity removal efficiency of M. stenopetala, where residual turbidity exceeded the maximum permissible limit of drinking water.

Dolollo (Fig. 1c) had an initial turbidity of 46 NTU, and M. subcordata reduced its turbidity to 11 NTU with the optimum dosage of $60 \mathrm{mg} / \mathrm{l}$, whereas $M$. stenopetala reduced the turbidity to $5 \mathrm{NTU}$ with optimum dosage of $20 \mathrm{mg} / \mathrm{l}$. M. stenopetala was superior to M. subcordata on Dolollo river 
Fig. 1 Change in turbidity of river water with different doses of coagulants
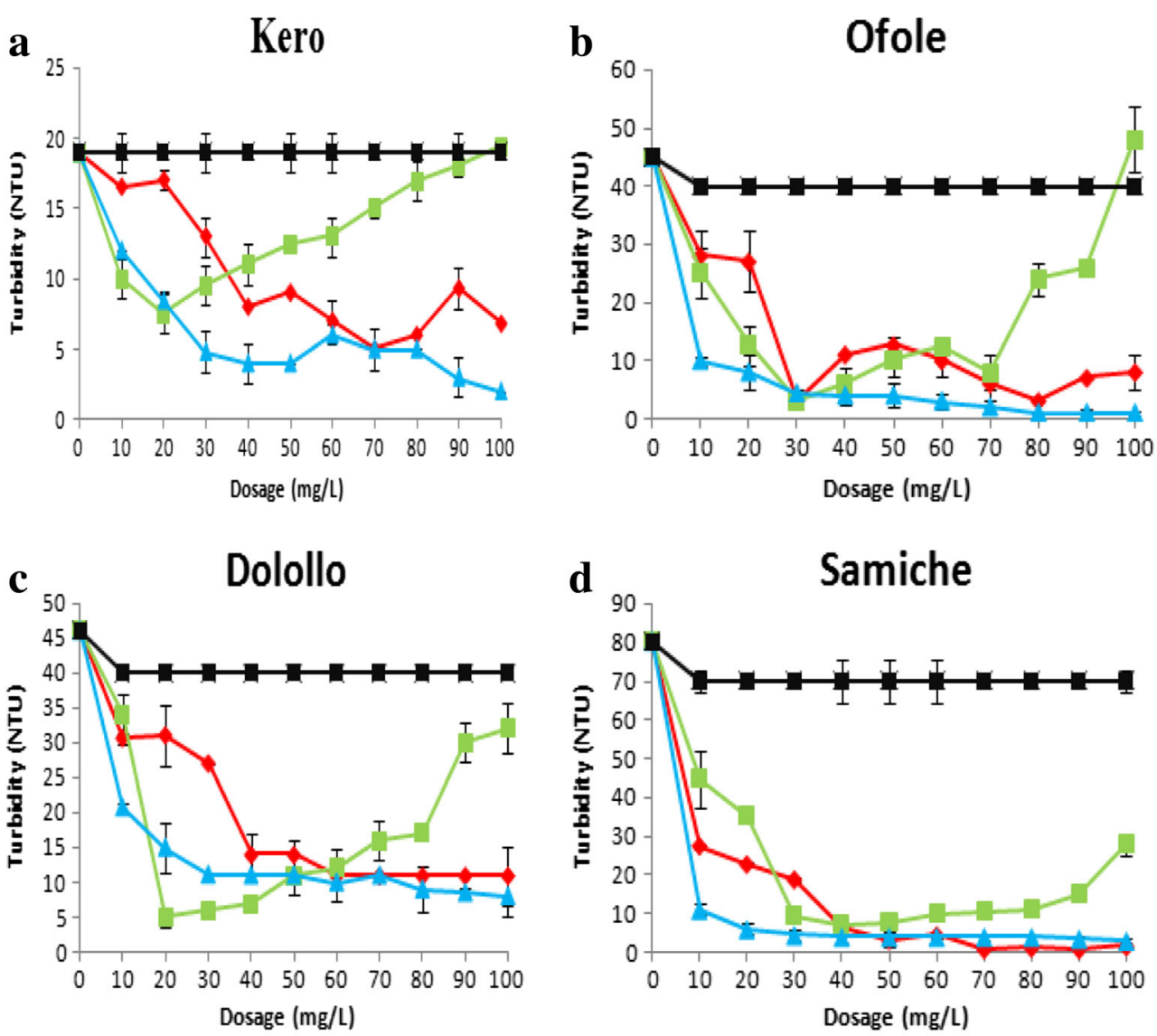

d Samiche

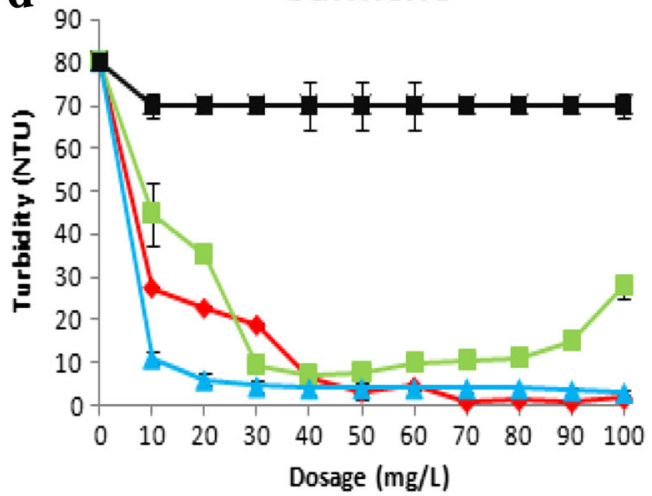

e

Gibe

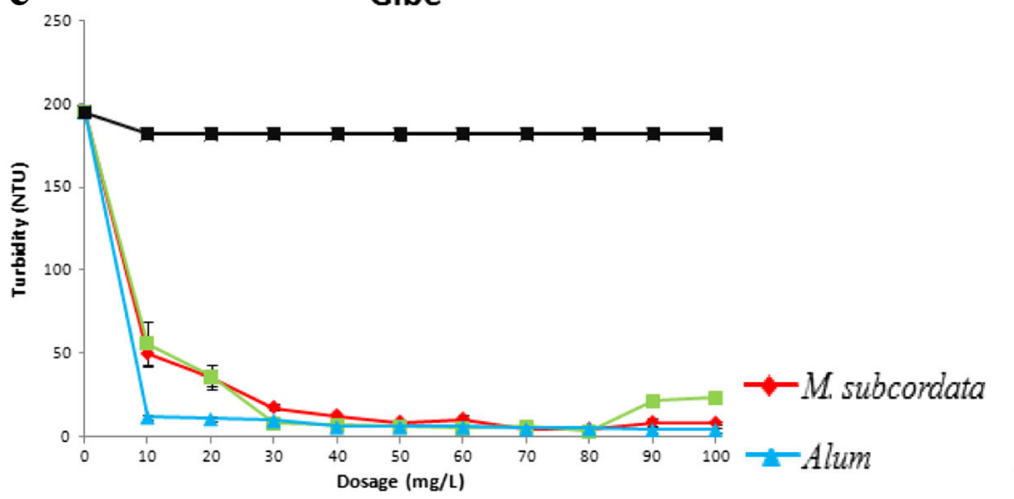

-M. stenopetala

Blank

water. The presence of color in this water sample might affect the efficiency of $M$. subcordata.

Samiche river water (Fig. 1d) had an initial turbidity of $80 \mathrm{NTU}$, and M. subcordata reduced its turbidity to 3 NTU with optimum dosage of $50 \mathrm{mg} / \mathrm{l}$. The same water source treated with $M$. stenopetala with an optimum dose of $40 \mathrm{mg} /$ 1 had residual turbidity of 7 NTU, which is above the World Health Organization (WHO) [38] guideline.

Gibe (Fig. 1e) river water showed the highest initial turbidity with $195 \mathrm{NTU}$, and $M$. subcordata reduced its turbidity to 5 NTU with the optimum dosage of $70 \mathrm{mg} / \mathrm{l}$. M. stenopetala reduced turbidity to $3.5 \mathrm{NTU}$ with an optimum dosage of $80 \mathrm{mg} / \mathrm{l}$. The best percentage reduction results for both plant species were obtained with this Gibe river water, where residual turbidity fall within the WHO [38] drinking water guideline.

The coagulation and flocculation processes were significantly affected by the doses of coagulants, one of the most important parameters to consider for optimization. Basically, suboptimum dosage would result in a poor performance in flocculation and consequently lead to failure to meet the water quality targets [39]. Above optimal amount, coagulant leads to an increase of treatment cost and therefore is not economically viable [40]. Overdosing results in the saturation of the polymer bridge sites and cause re-stabilization of the destabilized particles and hence would also disturb particle settling [41]. This phenomenon happens if the mechanism of turbidity 
Table 2 Removal of total coliform from surface water using M. subcordata, M. stenopetala, and chlorine as a positive control

\begin{tabular}{|c|c|c|c|c|c|c|c|c|}
\hline \multirow[t]{3}{*}{ River } & \multirow{3}{*}{$\begin{array}{l}\text { Initial turbidity } \\
\text { (NTU) }\end{array}$} & \multirow{3}{*}{$\begin{array}{l}\text { Initial microbial load } \\
(\mathrm{cfu} / 100 \mathrm{ml})\end{array}$} & \multicolumn{6}{|c|}{ Microbial load after treatment (cfu/100 ml) } \\
\hline & & & \multicolumn{2}{|l|}{$\begin{array}{l}\text { Positive } \\
\text { control }\end{array}$} & \multicolumn{2}{|c|}{ M. stenopetala } & \multicolumn{2}{|c|}{ M. subcordata } \\
\hline & & & Average & SD & Average & SD & Average & $\mathrm{SD}$ \\
\hline Kero & 20 & 179 & 0 & 0 & 0 & 0 & 0 & 0 \\
\hline Ofole & 45 & 167 & 0 & 0 & 0 & 0 & 0 & 0 \\
\hline Dolollo & 46 & 173 & 1 & 1.4 & 0 & 0 & 0 & 0 \\
\hline Samiche & 80 & 178 & 1 & 1.4 & 2 & 2.8 & 2 & 2.8 \\
\hline Gibe & 195 & 189 & 2 & 1.4 & 4 & 2.8 & 3 & 2.8 \\
\hline
\end{tabular}

removal is through adsorption and bridging. Overdosing may also lead to charge reversal and subsequent re-stabilization of destabilized particles if the mechanism of turbidity removal is linked with adsorption and charge neutralization. In the current study, we considered optimum dosage where residual turbidity was in the range of WHO guideline or the lowest residual turbidity even though the guideline could not be met. For instance, the lowest residual turbidity of Samiche river water treated with extracts of $M$. subcordata was $0.54 \mathrm{NTU}$ with a dosage of $90 \mathrm{mg} / \mathrm{l}$, but it was possible to achieve $3 \mathrm{NTU}$ with a dosage of $50 \mathrm{mg} / \mathrm{l}$. Thus, we considered $50 \mathrm{mg} / \mathrm{l}$ as an optimum dosage to treat Samiche river water using extracts of M. subcordata. Having this in mind, overdosing did not significantly affect the performance of $M$. subcordata unlike M. stenopetala, where increasing dosage above optimal further augmented residual turbidity. The presence of lipids may contribute to the poorer performance of $M$. stenopetala with increasing dosages in addition to the phenomenon of restabilization of destabilized particles.

The results also showed that initial turbidity and optimum dosage are not directly related. For instance, the optimum dosage used to treat Dolollo river water (46 NTU) with extracts of M. subcordata, M. stenopetala, and alum were 60, 20, and $30 \mathrm{mg} / \mathrm{l}$, respectively. However, 70, 20, and $40 \mathrm{mg} / \mathrm{l}$ were optimum dosages used to treat Kero river water (20 NTU) using the same coagulants. This evidence is different from those reported by Katayon et al. [18], as they documented that the optimum dosage of $M$. oleifera increased with increasing initial turbidity. This difference might be due to unlike experimental setups, namely, the type of water used. The present study was performed with natural surface water, while the previous one was conducted on synthetic water made up of kaolin. Surface water characteristics, type and size of particles, alkalinity, and other process variables may vary from river to river, which clearly affects the performance of coagulants, unlike synthetic water samples.

The present result also indicated that both plant species and alum had better coagulation efficiency on higher turbidity than low turbidity. At higher turbidity, less sedimentation time was required to coagulate turbid river water (data not shown). For instance, turbidity of Kero river (20 NTU) was reduced to $17 \mathrm{NTU}$ after $2 \mathrm{~h}$ of settling time using extracts of M. subcordata. However, at higher-turbidity range (195 NTU), the turbidity was reduced to 14.7 NTU after $2 \mathrm{~h}$ of sedimentation time. This phenomenon is due to the fact that turbidity increases with suspended particles, which can readily form interparticle bridges that enable them to settle down easily [42]. Other plant coagulants were also reported to allow better turbidity removal efficiency at high-turbidity ranges than of lowturbidity waters in both synthetic and natural raw water samples [19, 26, 34, 40, 43]. For instance, [40] reported the removal efficiency of Cicer arietinum on higher turbidity (120 NTU)
Table 3 Removal of fecal coliform and E. coli from surface water using M. subcordata, M. stenopetala, and chlorine as a positive control

\begin{tabular}{|c|c|c|c|c|c|c|c|c|}
\hline \multirow[t]{3}{*}{ Rivers } & \multirow{2}{*}{\multicolumn{2}{|c|}{$\begin{array}{l}\text { Initial microbial load } \\
\text { (cfu/100 ml) }\end{array}$}} & \multicolumn{6}{|c|}{ Microbial load after treatment (cfu/100 ml) } \\
\hline & & & \multicolumn{2}{|c|}{ Positive control } & \multicolumn{2}{|c|}{ M. stenopetala } & \multicolumn{2}{|c|}{ M. subcordata } \\
\hline & $\begin{array}{l}\text { Fecal } \\
\text { coliform }\end{array}$ & E. coli & $\begin{array}{l}\text { Fecal } \\
\text { coliform }\end{array}$ & E. coli & $\begin{array}{l}\text { Fecal } \\
\text { coliform }\end{array}$ & E. coli & $\begin{array}{l}\text { Fecal } \\
\text { coliform }\end{array}$ & E. coli \\
\hline Kero & 152 & 166 & 0 & 0 & 0 & 0 & 0 & 0 \\
\hline Ofole & 164 & 158 & 0 & 0 & 0 & 0 & 0 & 0 \\
\hline Dolollo & 168 & 160 & $2 \pm 2$ & 0 & $1 \pm 1$ & $2 \pm 1$ & 0 & $1 \pm 1$ \\
\hline Samiche & 159 & 153 & $2 \pm 1$ & $1 \pm 0$ & 0 & 0 & $1 \pm 1$ & 0 \\
\hline Gibe & 168 & 156 & $1 \pm 1$ & $2 \pm 2$ & $1 \pm 1$ & 0 & 0 & 0 \\
\hline
\end{tabular}


Table 4 Removal of heterotrophic bacteria from surface water using M. stenopetala, M. subcordata, and chlorine as a positive control

\begin{tabular}{|c|c|c|c|c|c|c|c|c|}
\hline \multirow[t]{3}{*}{ River } & \multirow{3}{*}{$\begin{array}{l}\text { Turbidity } \\
\text { (NTU) }\end{array}$} & \multirow{3}{*}{$\begin{array}{l}\text { Initial microbial load (cfu/ } \\
100 \mathrm{ml})\end{array}$} & \multicolumn{6}{|c|}{ Microbial load after treatment $(\mathrm{cfu} / 100 \mathrm{ml})$} \\
\hline & & & \multicolumn{2}{|l|}{$\begin{array}{l}\text { Positive } \\
\text { control }\end{array}$} & \multicolumn{2}{|c|}{ M. stenopetala } & \multicolumn{2}{|c|}{ M. subcordata } \\
\hline & & & Average & SD & Average & $\mathrm{SD}$ & Average & $\mathrm{SD}$ \\
\hline Kero & 20 & 139 & 0 & 0 & 0 & 0 & 0 & 0 \\
\hline Ofole & 45 & 118 & 2 & 2.8 & 3 & 1.4 & 1 & 1.4 \\
\hline Dolollo & 46 & 129 & 2 & 2.8 & 4 & 2.8 & 2 & 1.4 \\
\hline Samiche & 80 & 117 & 3 & 1.4 & 4 & 2.8 & 3 & 2.8 \\
\hline Gibe & 195 & 126 & 3 & 1.4 & 4 & 2.8 & 3 & 2.8 \\
\hline
\end{tabular}

and lower turbidity ( $35 \mathrm{NTU}$ ) to be 94.1 and $60 \%$, respectively, with an effective dose of $100 \mathrm{mg} / \mathrm{l}$. A study conducted by [19] on shallow well water, as found in Malawi, indicated that M. oleifera had a removal efficiency of $95 \%$ at 24 NTU with the optimum dose of $250 \mathrm{mg} / \mathrm{l}$. [40] reported $100 \mathrm{mg} / \mathrm{l}$ as an optimum dosage for Dolichos lablab at 100 NTU, where $89 \%$ of turbidity removal efficiency were achieved.

Alum showed the highest coagulation activity within a short period of sedimentation time for all tested river water samples (data not shown); however, with increasing sedimentation time, extracts from both plant species became as effective as the alum counterpart. Plant coagulants were even slightly more efficient $(93.5 \%)$ than alum $(90 \%)$ on Ofole river water samples (46 NTU). Such result is possible and in agreement with previous work using extracts of $C$. arietinum, where natural coagulant also outperformed alum [34]. Alum equally reduced turbidity of all, except Dolollo, river water samples to below $5 \mathrm{NTU}$, which is the maximum permissible limit of WHO standard for drinking water.

\section{Performance of Indigenous Plant Species as Disinfectant}

Both $M$. subcordata and M. stenopetala exhibited excellent performance on the reduction of microbial load (total coliform, fecal coliform, E. coli, and heterotrophic bacteria) as shown in Tables 2, 3, and 4. About $99.9 \%$ of microbial load removal

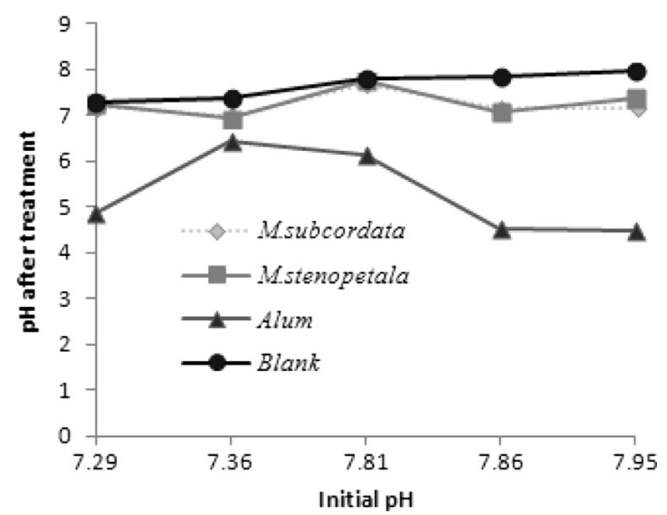

Fig. 2 Change in $\mathrm{pH}$ of river water samples treated with optimum doses of coagulants were observed for both M. subcordata and M. stenopetala, which is comparable to chlorine disinfection. A higher percentage of microbial elimination could be observed for lowerturbidity $(99.9 \%)$ than higher-turbidity levels (96\%). This higher percentage of microbial load removal from lowturbidity water than high-turbidity water could be due to the increment of suspended particles in high-turbidity water which protect microbes from the action of extracts.

A similar study conducted by [40] showed efficient reduction (89-96 \%) of total coliform from turbid water. [30] also reported a complete removal of coliforms from turbid water using seed extracts of $P$. ovata. As previously elucidated for other plant coagulants, the antimicrobial effect may be attributed to both flocculation [44] and bactericidal action [45]. The presence of alkaloids and tannins in plant species could contribute to antimicrobial activities [46]. Bacterial re-growth was raised as a big concern of natural coagulants and can be improved by purification of the active agent; thus, purification further eliminates additional nutrient and organic content [47]. Nevertheless, residual disinfection would be crucial to attain a level of zero colony-forming unit in treated water to meet the quality of the drinking water standards [19].

\section{Effect of the Coagulants on $\mathrm{pH}$}

The coagulation of $M$. stenopetala and $M$. subcordata revealed no significant changes on the $\mathrm{pH}$ of river water samples (Fig. 2). However, the same river water treated with alum decreased from 7.29 to 4.51 , which makes such treated water strongly acidic. When dissolved in water, the aluminum ions are hydrolyzed and it lowers the $\mathrm{pH}$ by increasing the concentration of $\mathrm{H}^{+}$. Most likely, the naturally occurring coagulants from plant materials possess a buffering property. The study conducted by [15] and [48] indicated that water treated with $M$. oleifera and $V$. unguiculata did not alter $\mathrm{pH}$ of water, whereas $\mathrm{pH}$ of a water sample augmented with increasing doses of $M$. oleifera and $J$. curcas [43]. Thus, using plant extracts for water treatment may have an enormous advantage by omitting the need for application of lime or bicarbonate to subsequently raise the $\mathrm{pH}$, and hence, it provides extra cost savings [19, 24, 48]. 


\section{Conclusions}

The batch experimental results indicated that extracts from $M$. subcordata tubers and $M$. stenopetala seeds were very effective in reduction of turbidity and microbial load. At optimum dose, large reductions of turbidity were achieved, but above the optimum dose, there was a reduced turbidity removal efficiency of M. stenopetala. The results revealed that different optimum dosages were needed to treat river water samples. For instance, $70 \mathrm{mg} / 1$ was an optimum dosage for $M$. subcordata tubers to treat Kero river water with initial turbidity of 20 NTU, whereas $20 \mathrm{mg} / \mathrm{l}$ was an optimum dosage to treat the same river water using seed extracts of $M$. stenopetala. The optimum dosage to treat the most turbid Gibe river water (195 NTU) was 70 and $80 \mathrm{mg} / 1$ using extracts of $M$. subcordata and M. stenopetala, respectively. The results revealed that turbidity removal efficiency of both plant species also varied from river to river under study. As a result, M. subcordata was more effective than M. stenopetala on Kero and Samiche river water, whereas M. stenopetala was more effective than M. subcordata on Dolollo and Gibe river waters. In general, extracts of both plant species showed comparable turbidity removal performance (up to $98 \%$ ) on high-turbidity waters. About $99.9 \%$ of microbial load removal was also observed for both M. subcordata and M. stenopetala, which is comparable to chlorine disinfection. However, microbial removal efficiencies of plant extracts were insufficient to fall within guideline values. Extracts from both plant species did not affect $\mathrm{pH}$ of water samples unlike alum. Generally, both the microbial and turbidity reduction findings revealed that both plant species can meet the requirements of drinking water quality in terms of microbial standards and maximum permissible limit of turbidity $(\leq 5 \mathrm{NTU})$ if they are used for household water treatment with further optimization.

Acknowledgments The authors thank the financial and logistic support provided by International Foundation for Science (IFS, W/5406-1); the Ethiopian Ministry of Water, Irrigation, and Energy; and Jimma University.

\section{References}

1. Committee on Economic Social and Cultural Rights CESCR (2003) The right to water. http://www.unhchr.ch/tbs/doc.nsf/0/a5458d1d1 bbd713fc1256cc400389e94. Accessed 04 April 2013

2. WHO, UNICEF (2012) Progress on sanitation and drinking water update. World Health Organization, Geneva

3. WHO (2011) Guideline for drinking-water quality: incorporating first addendum recommendations, 3rd edn. World Health Organization, Geneva

4. Clasen T, Brown J, Collin S (2006) Preventing diarrhoea with household ceramic water filters: assessment of a pilot project in Bolivia. Int J Environ Health Res 16(3):231-239

5. Hutton G, Haller L, Bartram J (2007) Global cost-benefit analysis of water supply and sanitation interventions. J Water Health 5:481-502
6. Arnold BF, Colford JM (2007) Treating water with chlorine at point-ofuse to improve water quality and reduce child diarrhea in developing countries: a systematic review and meta-analysis. AmJTrop Med Hyg 76(2):354-364

7. Sobsey MD, Stauber CE, Casanova LM, Brown JM, Elliott MA (2008) Point of use household drinking water filtration: a practical, effective solution for providing sustained access to safe drinking water in the developing world. Environ Sci Technol 42:4261-4267

8. WHO (2002) Reducing risks, promoting healthy life. World Health Organization, Geneva

9. Hutton G, Haller L (2004) Evaluation of the costs and benefits of water and sanitation improvements at the global level. World Health Organization, Geneva

10. Lantagne D, Preston PEK, Blanton E, Kotlarz N, Gezagehn H, Van Dusen E, Berens J, Jellison K (2011) Hypochlorite solution expiration and stability in household water treatment in developing countries. J Environ Eng 131-136

11. Sadiq R, Rodriguez MJ (2004) Disinfection by-products (DBPs) in drinking water and the predictive models for their occurrence. Sci Total Environ 321(1-3):21-46

12. Flaten TP (2001) Aluminum as a risk factor in Alzheimer's disease, with emphasis on drinking water. Brain Res Bull 55:187-196

13. Miu AC, Andreescu CE, Vasiu R, Olteanu AI (2003) A behavioral and histological study of the effects of long-term exposure of adult rats to aluminum. Int J Neurosci 113:1197-1211

14. Campbell A, Becaria A, Lahiri DK, Sharman K, Bondy SC (2004) Chronic exposure to aluminum in drinking water increases inflammatory parameters selectively in the brain. J Neurosci Res 75:565-572

15. Ndabigengesere A, Narasiah KS, Talbot BG (1995) Active agents and mechanism of coagulation of turbid waters using Moringa oleifera. Water Res 29:703-710

16. Ndabigengesere A, Narasiah KS (1998) Quality of water treated by coagulation using Moringa oleifera seeds. Water Res 32(3):781-791

17. Ghebremichael K, Gunaratna KR, Henriksson H, Brumer H, Dalhammar G (2005) A simple purification and activity assay of the coagulant protein from Moringa oleifera seed. Water Res 39:2338-2344

18. Katayon S, Noor MMM, Asma M, Ghani LA, Thamer AM, Azni I, Ahmad J, Khor BC, Suleyman AM (2006) Effects of storage conditions of Moringa oleifera seeds on its performance in coagulation. Bioresour Technol 97:1455-1460

19. Pritchard M, Mkandawire T, Edmondson A, O'Neill JG, Kululanga G (2009) Potential of using plant extracts for purification of shallow well water in Malawi. Phys Chem Earth 34:799-805

20. Pritchard M, Craven T, Mkandawire T, Edmondson AS, O’Neill JG (2010) A study of the parameters affecting the effectiveness of Moringa oleifera in drinking water purification. Phys Chem Earth 35:791-799

21. Madsen M, Schlundt J, Omer EFE (1987) Effect of water coagulation by seeds of Moringa oleifera on bacterial concentrations. J Trop Med Hyg 90:101-109

22. Yongabi KA (2010) Biocoagulants for water and waste water purification: a review. Int Rev Chem Eng 2(3):444-458

23. Choy SY, Prasad KMN, Wu TY, Ramanan RN (2015) A review on common vegetables and legumes as promising plant-based natural coagulants in water clarification. Int J Environ Sci Technol 12:367-390

24. Choy SY, Prasad KMN, Wu TY, Raghunandan ME, Ramanan RN (2014) Utilization of plant-based natural coagulants as future alternatives towards sustainable water clarification. J Environ Sci 26(11):2178-2189

25. Megersa M, Beyene A, Ambelu A, Woldeab B (2014) The use of indigenous plant species for drinking water treatment in developing countries: a review. J Bio Env Sci 5(3):269-281

26. Yongabi AK, Lewis MD, Harris LP (2011) Indigenous plant based coagulants/disinfectants and sand filter media for surface water treatment in Bamenda, Cameroon. Afr J Biotechnol 43:8625-8629 
27. Tassinari B, Doherty S, Marison IW (2013) Submicron capsules extracted from rapeseed as novel flocculant agents for the treatment of turbid water. Water Res 47:4957-4965

28. Fatombi JK, Lartiges B, Aminou T, Barres O, Caillet C (2013) A natural coagulant protein from copra (Cocos nucifera): isolation, characterization and potential for water purification. Sep Purif Technol 116:35-40

29. Adams FV, Mulaba-Bafubiandi AF (2014) Application of rice hull ash for turbidity removal from water. Phys Chem Earth 72-75:73-76

30. Ramavandi B (2014) Treatment of water turbidity and bacteria by using a coagulant extracted from Plantago ovata. Water Resour Ind 6:36-50

31. Kukic DV, Sciban MB, Prodanovic JM, Tepic AN, Vasic MA (2015) Extracts of fava bean (Vicia faba L.) seeds as natural coagulants. Ecol Eng 84:229-232

32. Sciban M, Mirjana GA, Mile TK (2006) Extraction and partial purification of coagulation active components from common bean seeds. Acta Periodica Technol 37:37-43

33. Marobhe NJ, Renman G, Jacks G (2007) The study of water supply and traditional water purification knowledge in selected rural villages in Tanzania. In: Boon EK, Hens L (eds) Indigenous knowledge systems and sustainable development. Kamla-Raj Enterprises, Delhi, pp. 111-120

34. Diaz A, Rincon N, Escorihuela A, Fernandez N, Chacin E, Forster CF (1999) A preliminary evaluation of turbidity removal by natural coagulants indigenous to Venezuela. Process Biochem 35:391-395

35. Megersa M, Beyene A, Ambelu A, Alebachew Z, Triest L (2015) Ethnomedicinal knowledge on water purification in selected rural areas of Ethiopia. Ethnobot Res Appl 14:393-403

36. Cheesbrough M (2006) Medical laboratory manual for tropical countries. Cambridge University Press, London

37. APHA (2005) Standard methods for examination of water and wastewater 21st edn. American Public Health Association, American Water Works Association and the Water and Environment Federation, Washington
38. WHO (2006) Guideline for drinking-water quality: incorporating first addendum recommendations, 3rd edn. World Health Organization, Geneva

39. Al-Sameraiy M (2012) A novel water pretreatment approach for turbidity removal using date seeds and pollen sheath. J Water Resour Prot 4:79-92

40. Asrafuzzaman M, Fakhruddin ANM, Alamgir HM (2011) Reduction of turbidity of water using locally available natural coagulants. ISRN Microbiol 1-6

41. Muyibi SA, Evison LM (1995) Optimizing physical parameters affecting coagulation of turbid water with Moringa oleifera seeds. Water Res 29:2689-2695

42. Birkner FB, Morgan JJ (1968) Polymer flocculation kinetics of dilute colloidal suspensions. J Am Wat Wks Ass 2:175-191

43. Abatneh Y, Yimer S, Sahu O (2014) Purification of drinking water by low cost method in Ethiopia. Appl Water Sci 4:357-362

44. Nwaiwu NE, Lingmu B (2011) Effect of settling time on turbidity removal using Moringa oleifera seed powder. Ozean J Appl Sci 4(3):195-208

45. Oluduro OA, Aderiye BI, Connolly JD, Akintayo ET, Famurewa O (2010) Characterization and antimicrobial activity of 4-( $\beta-d-$ glucopyranosyl-1 $\rightarrow$ 4- $\alpha$-1-rhamnopyranosyloxy)-benzyl thiocarboxamide; a novel bioactive compound from Moringa oleifera seed extract. Folia Microbiol 55(5):422-426

46. Ejelonu BC, Oderinde RA, Balogun SA (2010) Chemical and biological properties of Jatropha curcas and Mucuna solan seed and seed oil. Libyan Agric Res Cen J Intl 4:263-268

47. Ghebremichael K (2007) Overcoming the drawbacks of natural coagulants for drinking water treatment. Water Sci Technol Water Supply 7(4):87-93

48. Marobhe NJ (2013) Effectiveness of crude extract and purified protein from Vigna unguiculata seed in purification of charco dam water for drinking in Tanzania. Int J Environ Sci 4:3 